論文・Paper

\title{
いふうし
}

\author{
石閒健市・元山宗之・橋詀源蔵・田中 稔 \\ （兵席県立工業試験場）
}

\begin{abstract}
いぶし瓦の製造でみられる表面污染物を分析し，その予防策を検討した。污染により製品表面の 光沢が低下する。赤外線吸収スペクトル，ガスクロマトグラフ及び質量分析計による測定の結果， 污染物質は主として芳香族化合物であり，2４個の縮合謤で構成されていた，燻化ガスの炭化水 素ガス濃度の増大につれて污染量も増加した。製品での污染は冷却過程で煙道に残存与る燻化ガス と $400^{\circ} \mathrm{C}$ 近辺で接触することで発生寸る。希釈した煄化ガスの使用により污染防止ができた。
\end{abstract}

(1979 体 5 月 21 月受付)

\section{Contamination Deposits of the Smoked Rooftiles}

\author{
Ken-ichi ISHIMA, Muneyuki MOTOYAMA, Genzo HASHIZUME and Minoru TANAKA \\ (Industrial Research Institute of Hyogo Prefecture, Kobe-shi 654)
}

\begin{abstract}
The surface contaminants on the smoked rooftiles deposited during the manufacturing process were analyzed and its prevention method was discussed. The contaminants are known to reduce the silver luster of the rooftiles. Infrared spectroscopic, gas chromatographic and mass spectroscopic analyses showed that the major components of the contaminants were condensed aromatic materials and some of the $2 \sim 4$ ring compounds were identified. The amount of contaminants increased with the increasing amount of hydrocarbons. The contaminants on the products were predominantly formed at about $400^{\circ} \mathrm{C}$ by the contact with the raw smoking gas remained in the flue. The dilution of smoking gas with inert gas prevented the formation of the contaminants.

[Received May 21, 1979]
\end{abstract}

Key-words : Smoked rooftile, Surface contaminant, Dilution of smoking gas

1. 緒讋

いぶし瓦の製造は加熱された粘土素地に炭化水菜成分 の多いガスを接触させ，粘土素地表面に炭素を主成分と する炭素質膜（以下単に炭素膜と称する）を形成させる 煄化工程の終了後, 生成した炭素膜が燃烍しないように 箪を密閉した状態で泠却され行われる.

現在, 広く使用されているガス焼成嚜では，燻化工程 での炭化水素ガスに烧成用然料と同一のブタン，プロパ ン等の LPG が使用されている。この種の窯で発坐の著 しい欠点とその防止に関して，著者らは既に表面光沢を 低下させる付着炭素 ${ }^{1}$ ，及び粘土瓦素地中の鉄化合物に 起因する“さび”に関して報告した.

ところで, ガス窯で発生の多い，いま一つの欠点に淡 路瓦の業者間で“しょうゅ”と称されている現象がある. これは窯から煙道への排気孔付近の製品に集中して発生 するもので, 図1に示すように瓦の炭素膜が油紋状に赤 かっ色となり，一部ラスター光沢を伴う場合もある。
そこで，以ぶし瓦のガス穼での燒成技術の確立を目的 とした研究の一環として,この表面炭棐膜の污染とその 抑制について検討した結果を報告する。

2. 实 験 方 法

\section{1 試 料}

工場より提供をうけた表面污染を生じた製品を直接試

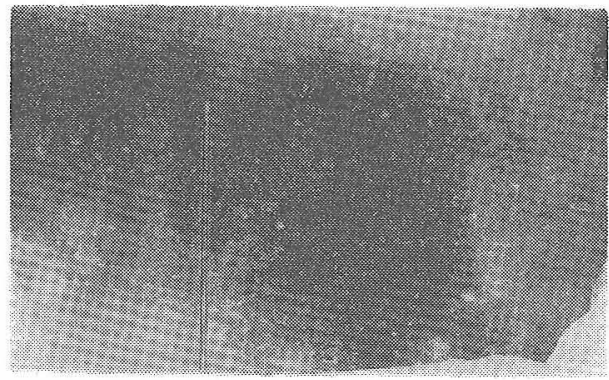

Fig. 1. Appearance of contaminants. 
料とした. これと並行して既報1)の方法で形成した良好 な炭素膜上に，実験で污染物質を沈着再現したものを参 照試料とした。

\section{2 污染物質の検討方法}

製品及び污染再現試料の表面を島津製作所製 EMXSM 型 X 線マイクロアナライザー（以下 EPMA と略 記する)で観察した.表面光沢をスガ試験機製色差計によ り，JIS Z 8722 の反射物体の測定法に準拠し刺激值 Y\% で比較した. 污染物質の同定は日本分光製赤外線吸収分 光計，日立製作所製ガスクロマトグラフ，及び日立製作 所製昇温ガスクロマトグラフとそれに直結した日立製作 所製 RMS-4 型質量分析計を用いて行った.

\section{3. 実験結果ट考察}

\section{1 製品に発生した污染物質}

製品の污染部分とそうでない部分とを EPMA で調べ たが，いずれも炭素が主成分であり，顕著な差は認めら れず，污染は炭素を主成分とする何らかの物質によって 生じていると考えられた。污染された製品を極性溶媒の アセトン, テトラヒドロフラン, 及び非極性溶媒のベン ゼンに室温で 10 日間浸漬したが, 外観の変化は認めら れず化学的に安定な物質で構成されていると判断され た. しかし，污染を生じた製品を透明なスチロール製の 試料箱に保存しておくと試料箱が失透してきたことか ら，一部揮発性の有機成分の存在が示唆された.

一方，污染を生じた製品を窒素ガスふん团気中で加熱 後観察すると, $600^{\circ} \mathrm{C}$ 以上では污染は完全に消失し，良 好ないぶし瓦の光沢を示した.

ところで，いぶし瓦製造時に存在する炭素供給源とし ては燻化ガスの炭化水素ガスのみである。したがって, いぶし瓦表面の污染物質は既報1で明らかにした，いぶ 乙銀光沢を与える平面状炭素膜が形成された後, なんら かの原因で炭化水素ガスが約 $600^{\circ} \mathrm{C}$ 以下で炭素膜上に 凝縮することにより発生すると推定される.

\section{2 污染の発生}

製品でみられる污染物質の発生条件を実験室的に再現 することで検討した. 長さ $1000 \mathrm{~mm}$ の管状炉での中央 加熱の場合, 炉端から中央部の設定温度との間に炉端か らの距離に対応した温度分布が存在する. あらかじめ作 製した良好な銀色光沢を有寸る試料を温度の確認された 炉内に配置し，プロパンガスのみを $20 \mathrm{ml} / \mathrm{min} ， 3$ 時間 流入した。この方法によれば污染に及ぼす温度のみの条 件が検討できる.

その結果, $600^{\circ} \mathrm{C}$ 以上及び $200^{\circ} \mathrm{C}$ 以下での試料面上 では污染は認められず，これらの中間の温度域で発生が 観察された. $300^{\circ} \mathrm{C}$ までに生成した污染はアセトンに容 易に溶解し，外観むタール状を呈している物質であっ た. しかし, $400^{\circ} \mathrm{C}$ 前後のものは製品の污染と同様の外

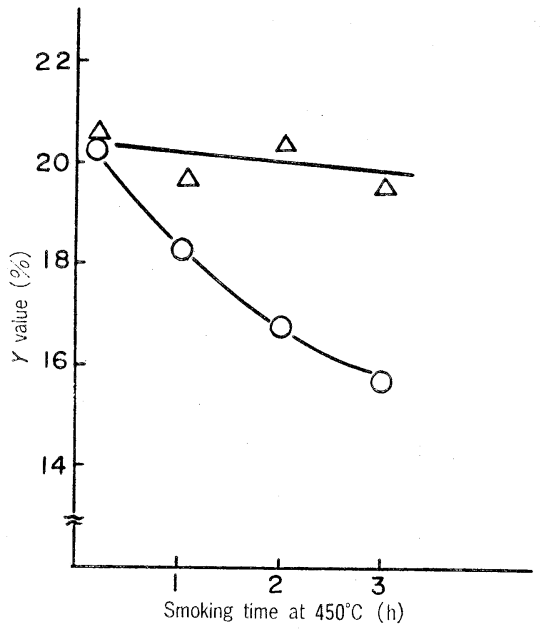

Fig. 2. Effect of dilution and smoking time on the $Y$ value of specimen surface.

$\triangle: \mathrm{C}_{3} \mathrm{H}_{8}: \mathrm{N}_{2}=1: 3, \mathrm{O}: \mathrm{C}_{3} \mathrm{H}_{8}$ only

観であり，アセトン等の溶媒では污染は除去されなかっ た.

次に, 燻化ガス濃度及び燻化時閒を変化させた時の炭 素膜の表面污染に及ぼす影響を調べ, 結果を図 2 に示 す. 污染の発生の程度は試料表面の明度で示され, 希釈 ガスを用いた場合は明度の低下が小さく表面の污染もほ とんど観察されなかった，また燻化時間が短いほど污染 も少なかった.

以上のことから, 污染の発生は炭化水素ガスの分解温 度によって決定され，その生成量は燻化ガスの炭化水素 ガス濃度, 燻化時間の増大につれ, 増加することが明ら かになった.

\section{3 污染物質の化学構造と発生機構}

これまでの結果から污染物質の輪郭と生成条件が判明 してきたので, 污染の発生機構と防止策の検討のため, その化学構造を明らかにすることを試みた，前述したよ うに污染物質は化学的に安定で表面炭素膜からの分離や はく離が極めて困難であるために, 主として機器による 解析を行った。

污染を生じを製品表面に $\mathrm{KBr}$ 粉末をのせスパーテル ですり合わせると, 污染物質が $\mathrm{KBr}$ 粉末に付着する. この $\mathrm{KBr}$ 粉末の赤外線吸収スペクトルを測定した. そ の結果の一部を図 3 に示す。 $2900 \mathrm{~cm}^{-1}$ の吸収はアルカ ンの $\mathrm{C}-\mathrm{H}$ 伸縮振動に起因するむのであり, $3030 \mathrm{~cm}^{-1}$ 付 近の吸収は芳香族 $-\mathrm{C}=\mathrm{H}$ 伸縮振動によるものである ${ }^{3)}$. 通常アルカンの炭素-水素伸縮振動に基づく赤外線吸収 強度は芳香族のそれに比して極めて大きい。污染物質の 場合これらの強度がほぼ等しいことが図 3 に示されてい る. したがって污染物質は相対的には芳香族化合物が非 常に多いと推定される. 


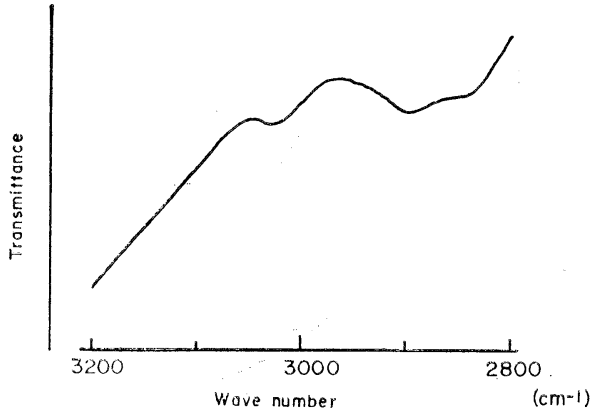

Fig. 3. IR spectrum of the contaminants on the smoked rooftile.

次に製品の污染部分と実験室で再現された污染部分と をそれぞれ小刀で削り取り，一部表面炭素膜も混在する もののガスクロマトグラフ測定を行った結果, 製品での 污染と実験室で得られた污染とは良く一致したパターン を示し，両者はほぼ同一の成分から構成されているもの と考えられる．なお，これらの主ピークの幅が非常に広 かったことから污染物質は, おそらく沸点, 分解温度の 異なる多くの物質の混合物から構成されていると考えら れたので，これらの分離測定に有効である昇温ガスク口 マトグラフでクロマト分離を行い，それと直結した質量 分析計によって各成分の同定を行った. 製品での污染物 質の昇温ガスクロマトグラムを図 4 に示す. カラム温度 が $100^{\circ} \sim 220^{\circ} \mathrm{C}$ の昇温でピークの分離が良好になった。 各成分について質量分析を行った結果を図 5 亿示す。こ れから図40番号(1)はナフタレン (2) 及び (3) はメチルナフタレン (4) はビフェニル

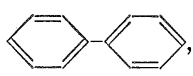

(5)アセナフチレン<smiles>C1=Cc2cccc3cccc1c23</smiles>
(10はフ

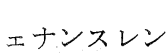<smiles>c1ccc2c(c1)ccc1ccccc12</smiles>

であると同定できた.

一方，污染物質をアセトンで 24 時間ソックスレ一抽 出を行った試料につき同様の測定を行った結果, 何らの 成分も検出されなかった. したがって, 図4で検出され た物質はアセトンで抽出できる比較的低沸点成分のみで あると考えられる. また抽出後の試料の外観にも全く変 化は認められなかった。

以上, 溶媒で污染物の着色が除去できないこと, 窒素 気流中 $600^{\circ} \mathrm{C}$ 以上の加熱で炭素膜と区別がつかなくな ること, 及び質量分析の結果から污染物質には比較的低 分子量の多環芳香族化合物も含有されているが，主体は かなり分子量の高い，高沸点の多環芳香族化合物である と考えられる.

ここで炭化水素ガスが多環芳香族を形成して污染物質

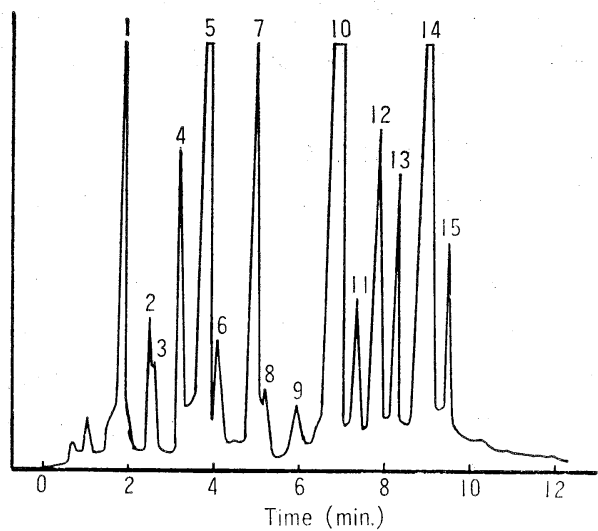

Fig. 4. Programmed temperature gas chromatogram of the contaminants of the product. Column : CV-1 3\% chromosolb WAW (60 80 mesh) Column temperature : $100^{\circ} \rightarrow 220^{\circ} \mathrm{C}$, Rate $6^{\circ} \mathrm{C} / \mathrm{min}$, Detector : FID, Identified molecular weight by mass spectra.

1 : Naphthalene<smiles>c1ccc2ccccc2c1</smiles>

2, 3 : Methyl naphthalene<smiles>Cc1ccc2ccccc2c1</smiles>

4: Biphenyl

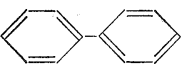

5 : Acenaphthylene<smiles>[C]=C</smiles>

10 : Phenanthrene
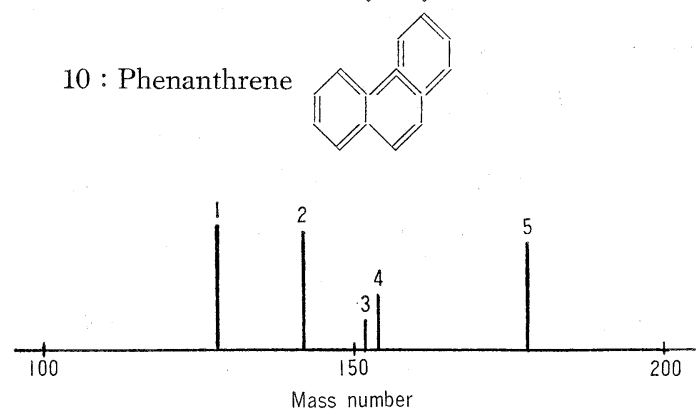

\begin{tabular}{ccl} 
Peak number & Molecular weight & \multicolumn{1}{c}{ Compound } \\
\hline 1 & 128 & Naphthalene \\
2 & 142 & Methyl naphtalene \\
3 & 152 & Acenaphthylene \\
4 & 154 & Biphenyl \\
5 & 178 & Phenanthrene \\
\hline
\end{tabular}

Fig. 5. Mass spectra of contaminants on the product.

となる機構を考察してみよう．燻化ガスはアルカンであ り，一般に $300^{\circ} \mathrm{C} ， 1$ 気圧以下では脱水素反応が起こ る4)，C-H結合エネルギーは $87 \mathrm{kcal} / \mathrm{mol}$ で C-C 結合 エネルギーは $59 \mathrm{kcal} / \mathrm{mol}$ であるから，変化する初期に は C-C 結合の切断が起こりやすく低分子量のラジカル 
が多量に発生する。これらが脱水素されてジエン，アル ケンが生成すると Diels-Alder 型の反応によって芳香 環が形成される。

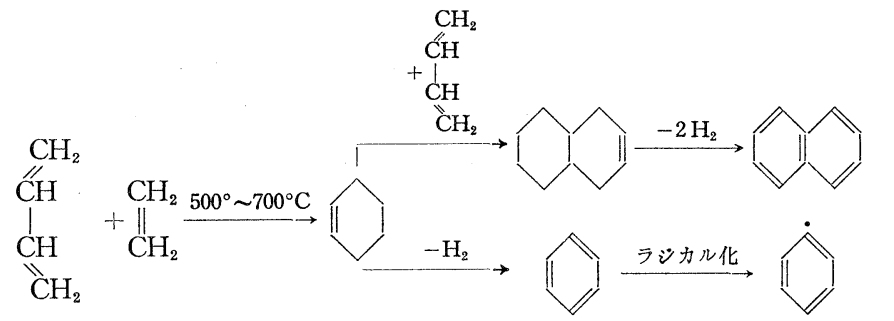

気を混入して同様の実験を行ったところ，顕著な変化は 認められなかった. 炭化水素の熱分解時に酸素が存在す ると脱水素反応が促進されることは良く知られているの で, 煙道付近には酸素が他所より多く存在 するために污染が発生するということも一 義的には否定できないが，上記の実験事実 以上に主要な原因であるとは考えられな い.

そこで燻化終了後の冷却過程での経時変 化を考えてみる. 燻化終了後の窐を密閉し た直後では, 煙道部内と䕓内との間の温度差は少なく, それらの間でのガスの圧力は平衡状態が保たれている. 時間経過につれ熱容量が小さく外気と熱交換をしやすい 煙道部内の温度低下速度は被熱物を含む致内に比して著 しく大きい, 一方, 嚜内の泠却速度は $500^{\circ} \sim 400^{\circ} \mathrm{C}$ に達 するまでは比較的大であり，この温度以下になると冷却 速度は極好小さくなる．これらの泠却過程中，宰内残 存ガスは $500^{\circ} \sim 400^{\circ} \mathrm{C}$ になるまでに熱分解されて水素を 主体とする残存ガスとなっているが，煙道部内には燻化 ガスが熱分解をうけないまま一部残存している.

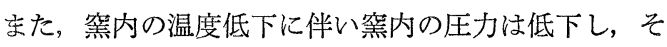
れと平衡を保つために煙道部の残存ガスが 炬内に流入 し, 梥内の被熱物と接触して熱分解をうける. 煙道部付 近の製品が煙道中に残存した燻化ガスと污染発生の温度 域で長時間接触する結果，污染が生じると考えられる.

ところで，このような污染を防止するには冷却過程で 燻化ガスが残存しないように不活性ガスで窵内を完全に 置換することが望まれる，しかしながら，この操作を行 うと一工程増加するので， 3.2 節で言及したように燻化 ガス自体をあらかじめ不活性ガスで希釈することによ り，既報1で示したように燻化工程での炭素膜生成が促 進される4)ことで，良好ないぶし銀光沢を有する平面状 炭素膜が形成され，しかも本報で検討した污染物質の沈 着をも防止できる.

\section{4. 結言}

いぶし瓦の製造で発生することのある，業者らに“し ょうゆ”之称される炭素膜の污染は, 燻化終了後の泠却 過程の $400^{\circ} \mathrm{C}$ 前後で, 炭化水素ガスと長時間接触する ことによって生成する多環芳香族を含む化合物によるも のである. 工場での発生は煙道に残存した燻化ガスと空 内の煙道部付近の製品が污染発生の温度で長時間接触す るため発生するものと考えられる. 污染の防止には泠却 時空内に燻化ガスが残存しないように不活性ガスで完全 に置換した状態で行うことが望ましいが，著者らが既 報1で示した良好な表面光沢を有する炭素膜を生成させ る，燻化時に希釈ガスを用いる方法は污染の防止に極め て有効であり，製造法の観点からも好ましいものである
Fig. 6. Deposition area of contaminants in the kiln. 
ことが判明した．污染物質は製品の商品価值を皆無にす るだけでなく，成分に芳香族化合物が含まれているため 作業環境上の見地からも発生の防止が望まれる。

謝辞本研究を行らに当たり，ガスクロマトグラフと 質量分析計によって試料の同定を行って頂いた兵庫県公害研究 所 奥野年秀第三研究部次長 並びに辻 正彦第三研究部主任研究 員に心から感謝致します.

文献

1）田中 稔, 元山宗之, 石間健市, 橋詰源蔵, 窯協, 84,
220-25 (1976).

2) 田中 稔, 石閒健市, 元山宗之, 橋詰源蔵, 窯協, 84, 450-52 (1976).

3) L.G. Bellamy "The Infra-red Spectra of Complex Molecules" John Wiley \& Sons. Inc. (1958).

4) J.E. Germain 著, 吉富末彦, 菊地英一共訳 “炭化水素の 接触コンバージョン”昭晃堂 (1972).

5) L.F. Fieser, M. Fieser "Advanced Organic Chemistry" Reinhold Publishing Company (1961).

6) 大谷杉郎, 石油学会誌, 18, 606-10 (1975).

7) A. Thomas, Comb. \& Flams, 6, 46 (1962).

論文・Paper

\title{
ヘキサフェライト系磁石の配向度亡磁気特性
}

\author{
佐 佐 嘉 彦・宇田応之 \\ (理化学研究所)
}

\begin{abstract}
一軸板状配向したへキサフェライト系磁石の異常な回折強度を，著者らが開発したテクスチャー パターン法により, 配向度の関数として説明することに成功した. この方法では, 配向体内の微結 晶の分布を, 基本的にはガウス型であると近似し, 試料の配向度を二つのパラメーターによって定 量的に表した. 同法の解析によれば等方性と呼ばれている試料でさえも，完全な無配向体とは見な し得ないことが分った. また, この方法では, 回折線の重なりをも勘案しているので, Lotgering 法よりも正確な配向度を見積もることができる.

5 種のヘキサフェライト磁石について, テクスチャーパターン法で見積もった配向度と, 磁気測 定から得られる配向の指標 $B_{\mathrm{r}} / 4 \pi M_{\mathrm{s}}$ との間, 及び，最大エネルギー積 $(B H)_{\max }$ との間に，い ずれも良い直線関係が得られた。

(1979 年 5 月 24 日受付)
\end{abstract}

\section{Dependence of the Degree of the Preferred Orientation on Magnetic Properties of the Hexaferrites}

\author{
Yoshihiko SASA and Masayuki UDA \\ (The Institute of Physical and Chemical Research, Wako-shi 351)
}

X-ray diffraction intensity distribution obtained from anisotropic hexaferrite magnets with an uniaxial orientation was explained quantitatively by use of the "Texture pattern technique" developed by one of the authors. The degree of the orientation or the magnitude of the deviation from a random distribution is presented by two parameters, a Gaussian constant $h$ and a randomness factor $b$. We could estimate more accurate degree of the orientation by this method than by the Lotgering's one because the diffraction peak overlapping in the case of the latter was not taken into account. Based on this method it was also concluded that the crystallite distribution even in so-called "isotropic" magnet was not completely random. A relationship between the degree of the orientation and $B_{\mathrm{r}} / 4 \pi M_{\mathrm{s}}$ or $(B H)_{\max }$ was linear.

[Received May 24, 1979]

Key-words : X-ray powder diffraction, Texture analysis, Degree of preferred orientation, Magnetic property, $\mathrm{BaO} \cdot 6 \mathrm{Fe}_{2} \mathrm{O}_{3}, \mathrm{SrO} \cdot 6 \mathrm{Fe}_{2} \mathrm{O}_{3}$ 